\title{
Preservando a memória do velho hospital
}

\author{
Preserving memories of the old hospital
}

Walmor João Piccinini

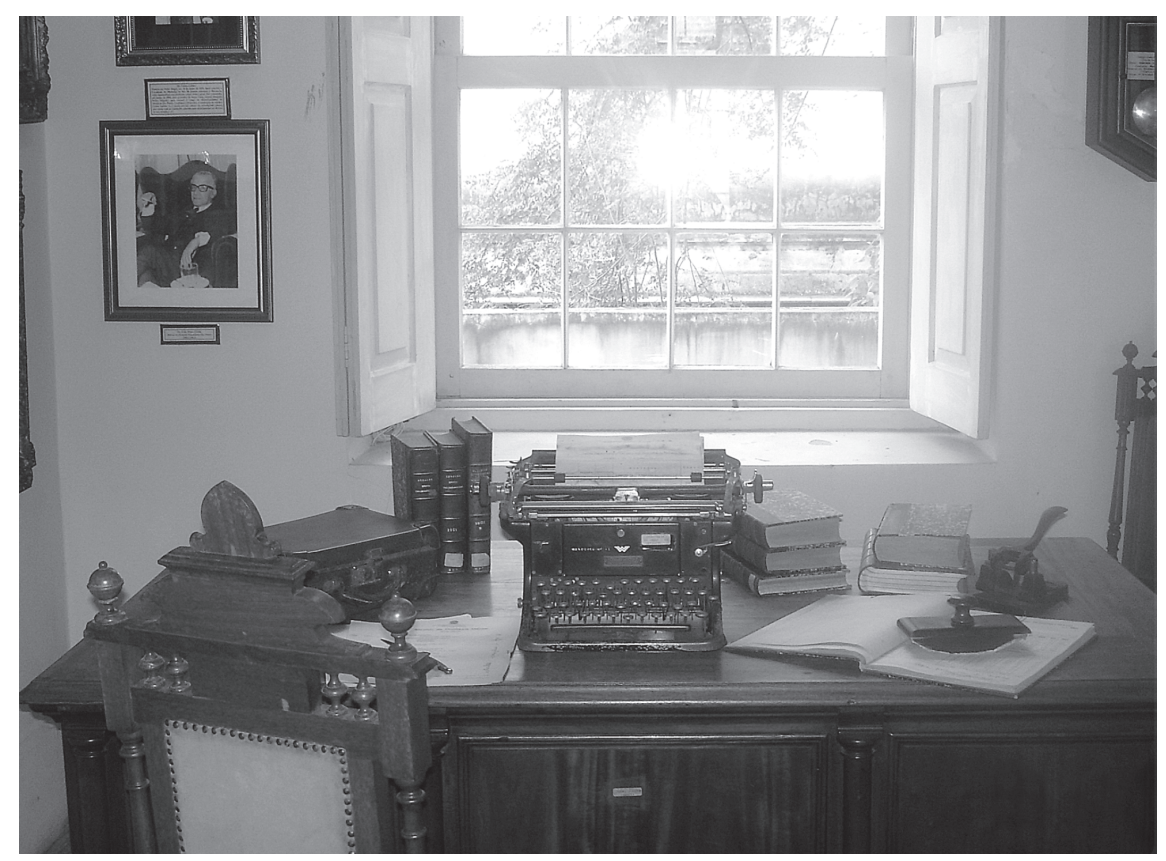

Sala de Exposição do Serviço de Memória Cultural Hospital Psiquiátrico São Pedro - 2007

A capa da nossa revista apresenta objetos que costumavam enfeitar a sala do diretor do Hospital Psiquiátrico São Pedro. Ao examinar detalhes da foto, lembrei-me de um clássico do diretor Michelangelo Antonioni (1912-2007), "Blowup", e pensei também que todos conheceriam o filme, mas ao investigar a data do seu lançamento, 1966, cheguei à conclusão de que, com exceção dos mais maduros, poucos lembrariam dele.

O filme, na época, despertou minha atenção por um detalhe de técnica fotográfica. Era utilizado o recurso de ampliação e detalhamento, e isso permitiu visualizar a arma de um crime em andamento. Ao examinar nossa foto, fiquei imaginando a ampliação de detalhes que pouco chamam a atenção numa mirada rápida. Num primeiro plano está uma máquina de escrever Continental, cujo modelo poderia ser de 1937. Numa ligeira pesquisa na Internet, encontrei à venda uma similar por R $\$ 100,00$. Triste destino desta e outras tantas máquinas de escrever nesses tempos de computadores. A própria idéia de ampliação fotográfica fica obsoleta se imaginarmos a capacidade do Google Earth e do recém lançado Google Sky.

Enfeitando a mesa, temos os tradicionais clássicos franceses, que eram leitura obrigatória dos psiquiatras do início do século XX.

Seguindo esse processo de ampliar a imagem, encontramos à esquerda um quadro com a imagem do Dr. Carlos Lisboa, primeiro diretor do Hospício. Ele nasceu em 1859, formou-se no Rio de Janeiro e veio trabalhar na sua terra. O Hospício São Pedro foi entregue para a Santa Casa para ser por ela administrado. O escolhido para ser o primeiro diretor foi esse jovem médico que recém chegara da capital da república. Carlos Lisboa assumiu em 1884 e ficou pouco tempo no cargo: uma doença fulminante o 
vitimou na flor da idade. Ele ficou quatro anos na direção do hospício, era clínico e estruturou o atendimento de acordo com esse conhecimento.

Abaixo da figura do primeiro diretor, temos outro quadro, com outro diretor, mas já nos anos 60. A imagem no quadro é a do Dr. Luiz Pinto Ciulla, que foi diretor em 1960-61. Ciulla foi um dos quatro primeiros psiquiatras concursados do então chamado Hospital São Pedro. Ele foi o primeiro colocado num concurso que tinha Mario Martins, Cyro Martins e Victor de Brito Velho. Todos eles participaram da formação da Sociedade de Psiquiatria, Neurologia e Neurocirurgia do Rio Grande do Sul, nesse mesmo ano de 1938 e cujo primeiro presidente foi o Dr. Jacinto Godoy. Ciulla foi sempre um fiel companheiro de Jacinto e com ele trabalhou no Sanatório São José. Em 1960, foi realizado no Rio de Janeiro um simpósio sobre depressão, e nele ocorreu o lançamento da imipramina no Brasil. Um dos trabalhos foi apresentado pelo Dr. Luiz Ciulla ${ }^{1}$.

Durante a gestão de Ciulla, foi criada a Divisão Melanie Klein, centro de treinamento de centenas de psiquiatras gaúchos. Os jovens psiquiatras formados nessa unidade aos poucos se espalharam pelo interior do hospital, chefiaram unidades e iniciaram uma transformação no modelo de atendimento. Esse tempo parece tão distante, mas ainda lembro a epopéia que foi a tomada da Divisão Pinel. Era um setor do hospital com mais de 1.000 pacientes, tinha áreas onde ninguém entrava, muito menos os médicos. Um grupo de médicos decidiu colocar os consultórios no pátio da divisão e foram irmanados nessa tarefa de enfrentar a loucura de peito aberto. Existe um trabalho publicado ${ }^{2}$ que trata da criação de um barzinho dentro da Divisão Pinel, e a moeda de troca era o cigarro. Nesse artigo são mostradas as primeiras tentativas de socialização num ambiente até então isolado do mundo. Discutia-se a influência dos conhecimentos psicanalíticos na melhora do atendimento em um hospital psiquiátrico.

A mesa e as cadeiras acompanharam a trajetória de inúmeros diretores e podem ser vistas em fotos de diferentes épocas. Discretamente, em cima de uma cadeira, está a maletinha de algum paciente. Certamente modesto, pois muito pouca coisa poderia ser colocada em um espaço tão diminuto.

A história do Hospital Psiquiátrico São Pedro nos remete a épocas em que a atividade médica era mais respeitada. O cargo de diretor do Hospital era o ápice da carreira de todo profissional. A chegada da clorpromazina em 1956 e da imipramina em 1960 trouxe uma revolução no tratamento: os internamentos foram diminuindo, as altas foram aumentando e, por fim, o hospital ficou reduzido a pacientes moradores, pessoas que lá estão por não terem para onde ir. O velho São Pedro foi sendo desativado, os investimentos minguaram, e uma estranha associação de extremos ainda batalha para liquidá-lo. Os que não querem gastar com a saúde da população nós podemos entender. Difícil é entender profissionais da saúde que adotam uma linha de negação da existência da doença mental como bandeira e tentam atrapalhar de todas as formas o trabalho de atendimento.

\section{Referências}

1. Ciulla LP. Contribuição ao tratamento das depressões com tofranil. J Bras Psiquiatr. 1960;9(1,2):79-92.

2. Santos MG, Haillot JC. Observações clínicas de um fenômeno sociológico num hospital público. J Bras Psiquiatr. 1970;19(3):21523. 